\title{
DISPARITAS ISLAM INDONESIA: ANTARA NEGARA ISLAM DAN NEGARA BANGSA
}

\author{
Mahir Amin \\ Fakultas Syariah IAIN Sunan Ampel Surabaya
}

\begin{abstract}
Abstrak: Diskursus negara Islam (Daulah Islamiayah ) di negara kita akhir-akhir ini boleh dibilang menjadi fenomena. Kecenderungan untuk menerapkan syariah Islam dalam negara atau pemerintahan merupakan gejala yang bukan hanya berkembang di indonesia tapi juga di banyak negara Muslim, seperti Pakistan, Yordania, Sudan, Mesir, Maroko, Kuwait, Iran, dan lain-lain. Munculnya fenomena gerakan Islam (harakah Islamiyah ) mulai dari yang berskala internasional seperti gerakan ikhwanul muslimun ,jamaah Murabitun, Tanzibul Jihad, Hizbut Tahrir, sampai yang berskala lokal seperti DI/TII,NII, Jama'ah Muslimun (Jamus) dan yang lainnya merupakan follow-up dari upaya meralisasikan aturan syariat dalam negara ( sebut saja negara Islam). Tulisan ini berusaha untuk mencari jawaban terhadap permasalahan-permasalahan yang muncul dari pandangan para pendukung dan penentang negara Islam terkait dengan konsep negara syariah dalam sistem politik Islam (Islamic State), serta penerapannya dalam sistem negarabangsa (nation state). Ada dua hal yang perlu digaris bawahi terkait hal ini yaitu (I) Apakah Islam memang berkaitan dengan penyelenggaraan negara dan (2) apakah politik Islam diarahkan untuk mencari dan mencapai konsesi kekuasaan, sehingga cita-cita Islam tercapai ?. Dalam upaya merelisasikan dan mewujudkan semangat politiknya tidak jarang terjadi "ketegangan" antara kelompok yang ingin menerapkan syari'ah sebagai simbolisasi negara Islam dalam aturan-aturan pemerintahan dengan kelompok yang menentangnya. Dan tak jarang terjadi berbagai tindak kekerasan dan bahkan terjadi kudeta terhadap pemerintahan yang sedang berjalan.
\end{abstract}

Kata Kunci: Disparitas, agama, negara. 


\section{Pendahuluan}

Sebelum membahas Islam dalam konsesi kekuasaan negara , ada baiknya kita melihat Islam pada periode awal kenabian . Suatu agama, baik yang mengaku sebagai agama wahyu maupun tidak, tidak bisa lepas dari pengaruh situasi asal-usulnya yang kompleks. Adanya campur tangan Tuhan sekalipun, tidak bisa terlepas dari pengaruh-pengaruh ini. Teologi Islam, sebagaimana dinyatakan oleh Al-Qur'an, tidak mengenal konsep campur tangan Tuhan yang semena-mena, Al-Qur'an (33:62)

Bahkan dalam persoalan pahala dan siksa Tuhan, berbeda dengan teologi Calvinis, bukan atas dasar tindakan Tuhan yang semena-mena. Al-Qur'an, (53:40)..

Tentu saja, petunjuk Allah (taufiq min Allah) tidak ditolak, tetapi petunjuk Allah itu, sepanjang perhatian teologi Al-Qur'an, tidaklah bersifat semena-mena. Taufiq (petunjuk Allah) dalam teologi Islam sesungguhnya merupakan potensi untuk bertindak yang diciptakan Tuhan, yang masih mempunyai kemungkinan dapat atau tidak dapat diaktualisasikan, karena manusia adalah "agen" yang bebas.

Proses historis juga sangat diperlukan dalam Islam. Sejarah bukanlah mitos, bukan pula suatu proyek arbitrer yang sama sekali tidak mempunyai kausalitas sosial. Al-Qur'an memang mempunyai pendekatan teleologis sebagaimana kisah nabi-nabi Israel yang diceritakan dengan penggambaran yang jelas, tetapi kausalitas tidaklah diabaikan begitu saja. Kemurkaan Allah kepada suatu bangsa atau seseorang diberlakukan ketika mereka mengabaikan proses kausalitas sosial dan berbuat menyimpang dari sunnah-Nya, baik secara fisik (hukum alam) maupun moral (hukum-hukum etik yang mengacu pada hudud Allah dalam AlQur'an). Al-Qur'an,( 53: 40.) dan al-Qur'an ( 21:46 ).

Dengan demikian kita melihat bahwa teologi Islam, sebagaimana dinyatakan Al-Qur'an, sama sekali tidak mengabaikan determinisme sejarah, tetapi sebaliknya, secara serius memperhatikan peristiwa sejarah serta pengaruh- 
pengaruhnya yang menentukan. Islam juga mencoba menanamkan kesadaran sejarah pada umatnya.

Apa yang dinyatakan secara jelas adalah bahwa kesadaran yang tepat diperlukan untuk memahami sesuatu dan mengambil hikmah dari peristiwa-peristiwa sejarah, dan bukan semata-mata persepsi inderawi yang dimiliki setiap orang.

Periode Islam Kenabian perlu dipahami setidaknya sesuai dengan "determinisme sejarah" dengan tepat. Hal ini tidak lain untuk menghindari kesalahpahaman. Istilah ini tidak menafikan lingkup yang sah bagi inisiatif manusia yang bagaimanapun sesuai dengan persepsi manusia tentang tujuan ilahiyah.

Bagaimana situasi Mekkah pada masa Nabi ? Mekkah sejak akhir abad kelima telah berkembang menjadi pusat perdagangan yang penting. "Mekkah menjadi makmur, karena lokasinya berada pada rute strategis dan menguntungkan dari Arabia Utara ke Arabia Selatan; Mekkah menjadi jalur utama perdagangan dan menjadi pusat pertemuan para pedagang dari kawasan Laut Tengah, Teluk Parsi, Laut Merah melalui Jeddah, bahkan dari Afrika. ${ }^{1}$

Masyarakat Mekkah sebagai mampu mengembangkan lembaga-lembaga pemilikan pribadi, memperbanyak keuntungan, menumuhkan disparitas ekonomi dan pemusatan kekayaan. Etika masyarakat perdagangan itu tentu saja bertabrakan dengan etika masyarakat kesukuan. Kebangkrutan sosial di Mekkah, sesungguhnya berakar pada konflik-konflik ini. Karena cepatnya perkembangan operasi perdagangan, beberapa pedagang yang memiliki keahlian yang berasal dari berbagai klan dan suku, terus menerus memperbanyak kekayaan pribadinya. Bahkan mereka membentuk korporasi bisnis antar-suku dan menerapkan monopoli pada kawasan bisnis tertentu di tempat asal mereka. Orang-orang lemah dan tersingkir dari persaingan bebas ini

'Asghar Ali Engineer, The Origin and Development of Islam, Orient and Longman, 1980, hal. 41.

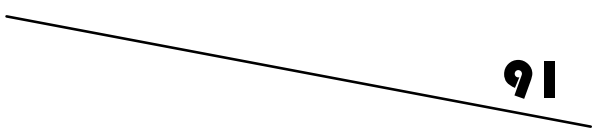


mencoba membentuk asosiasi yang mereka sebut Hilf al-Fudul (Liga Orang-orang Tulus).

Nabi tergabung dalam Liga ini dan selalu merasa bangga dengan persekutuannya dengan Liga tersebut. Berbagai penjelasan telah ditawarkan untuk pembentukan Liga ini. ${ }^{2}$

Demikian pula orang-orang miskin, lemah, terlantar dan tak terlindungi yang terjebak dalam proses sosial yang tak terelakkan itu merebak di pinggiran kota perdagangan Mekkah. Dalam struktur masyarakat kesukuan, hancurnya struktur masyarakat kesukuan di Mekkah bertanggungjawab terhadap terbukanya pintu ketegangan sosial ${ }^{3}$. Sementara itu, monopoli perdagangan sedang muncul di Mekkah. ${ }^{4}$

Akibat terjadinya kebangkrutan sosial di Mekkah Nabi lalu melakukan tindakan hijrah ke Madinah membangun strategi dakwah yang lebih komprehensif. Di kota Madinah inilah Nabi membangun tatanan sosial berdasarkan kesepatan bersama dengan suku-suku lain berdampingan secara damai. Islam yang Hanif, Islam yang rahmatan lil aalamin.

${ }^{2}$ Watt mencatat, "Mereka membentuk suatu aliansi antar klan, yang dapat kita sebut sebagai Liga orang-orang Tulus--nama-nama lain juga sering kita temukan. Muhammad menghadiri pertemuan yang pembentukan Liga itu, bahkan ia menyetujui pembentukan liga itu. Tujuan liga itu adalah untuk menjaga integritas perdagangan, tapi di balik itu, liga berkepentingan untuk mencegah keluarnya pedagang Yaman dari pasar Mekkah, karena liga merasakan kesulitan jika harus mengirimkan sendiri kafilah mereka ke Yaman yang selama ini sangat profesional dalam perdagangan antar kota terutama Mekkah dan Syria. (M. Montgomery Watt, Muhammad, Prophet and Statesman, London, 1961), hal. 9.

${ }^{3}$ HAR. Gibb berkomentar, Mekkah ketika itu menyimpan sisi gelap. Kejahatan dalam masyarakat pedagang kaya adalah hal yang biasa, begitu juga kesenjangan yang amat jauh antara kaya dan miskin, perbudakan dan persewaan manusia dan tajamnya pertentangan kelas-kelas sosial. Hal ini jelas dari keluhan Nabi Muhammad atas ketidakadilan sosial dan inilah yang menyebabkan guncangan keras dalam dirinya. (HAR. Gibb, Mohammadanism, Oxford, 1969), hal. I I

${ }^{4}$ Pada permulaan tahun Masehi, salah satu dari suku-suku Arab bernama Quraisy menduduki Mekkah. Kota ini terdiri dari wilayah-wilayah, dan setiap wilayah terdapat klan yang termasuk suku Quraisy. Penduduk Mekkah ikut serta dalam perdagangan baik ke dalam maupun ke luar, dan inilah yang menyebabkan kemakmuran kota ini sekaligus menyebabkan kesenjangan oendapatan yang besar. Dalam suku Quraisy sendiri, terdapat keluarga-keluarga kaya terlibat dalam perdagangan dan praktek riba. (A.P. Petrovsky, Islam da Iran, Persian, diterjemahkan oleh Karim Kashawarz, Teheran, 1950) hal. 16. 
Allah menjanjikan dalam Al-Qur'an untuk mengutus seorang pembimbing atau seorang pemberi peringatan ketika suatu masyarakat menghadapi krisis sosial dan krisis moral. Muh\}ammad dipilih sebagai instrumen kemahabijaksanaan Tuhan untuk membimbing dan membebaskan rakyat Arabia dari krisis moral dan sosial yang lahir dari penumpukkan kekayaan yang berlebih-lebihan sehingga menyebabkan kebangkrutan sosial. Islam bangkit dalam setting sosial Mekkah, sebagai sebuah gerakan keagamaan, namun lebih dari itu, ia sesungguhnya sebuah gerakan transformasi dengan implikasi sosial ekonomi yang sangat mendalam. Islam, dengan kata lain, menjadi tantangan serius bagi kaum monopolis Mekkah.

Fakta bahwa Islam lebih dari sekedar sebuah agama formal, tetapi juga risalah yang agung bagi transformasi sosial dan tantangan bagi kepentingan-kepentingan pribadi, dibuktikan oleh penekanannya pada shalat dan zakat. Dalam kebanyakan ayat AlQur'an, shalat tidak pernah disebut tanpa diiringi dengan zakat. Zakat, seperti digariskan Al-Qur'an, dimaksudkan untuk distribusi kekayaan kepada fakir dan miskin, untuk membebaskan budakbudak, membayar hutang mereka yang berhutang dan memberikan kemudahan bagi ibnu as-sabil (yang secara harfiah diartikan sebagai infrastruktur bagi orang-orang yang berpergian). Di Arab ketika itu, langkah-langkah seperti itu dirasakan sebagai hal baru yang sangat revolusioner, karena itu masyarakat bisnis Mekkah, yang merasa kepentingannya terancam melakukan perlawanan terhadap Nabi.

Signifikansi transformatif dari ajaran Islam, lebih lanjut dibuktikan oleh kenyataan bahwa ajaran-ajaran itu lahir di dalam polarisasi kekuatan-kekuatan sosial. Budak-budak dan orangorang yang tidak pandai berdagang di satu pihak, dan pemudapemuda radikal di pihak lain, bersatu mendukung Nabi. Orangorang kafir yang menentang risalah Nabi merasakan hal itu sebagai pukulan keras bagi kepentingan mereka. Masalah ini diisyaratkan dalam Al-Qur'an (34:34).

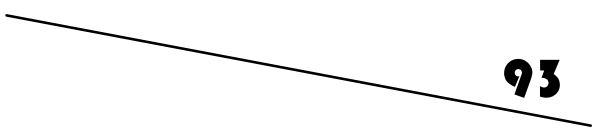


Tapi Al-Qur'an memperingatkan orang-orang kaya ini:

"Dan sekali-kali bukanlah harta dan (bukan) anak-anak kamu yang mendekatkan kamu kepadaKu sedikitpun; tetapi orang yang beriman dan mengerjakan amal saleh." 5

Dengan demikian sangat jelas bahwa orang-orang kafir dalam arti yang sesungguhnya pada kehidupan sosila masyarakat adalah orang-orang yang menumpuk kekayaan dan menghidupkan terus menerus ketidakadilan serta merintangi upaya-upaya menegakkan keadilan dalam masyarakat. Keadilan, sebagaimana nanti akan kita lihat, merupakan salah satu aspek penting dalam ajaran Islam di bidang ekonomi.

Sebagaimana yang dikemukakan dengan tepat oleh Muhłammad Ahmad Khalfallah, pada dasarnya Nabi Muh\}ammad adalah seorang revolusioner dalam ucapan maupun dalam perbuatannya. Ia bekerja demi perubahan radikal pada struktur masyarakat sosial pada masanya. ${ }^{6}$ Ia mengabaikan kemapanan di kotanya, yang telah dikuasai oleh orang-orang kaya dan penguasa Mekkah. Rumusan yang didakwahkan, La ilaha illa Allah, dengan sendirinya sangat revolusioner dalam implikasi sosial-ekonominya. Kekuatan revolusioner manapun, pertamatama haruslah merombak status-quo, sebelum alternatif lainnya bisa berfungsi. Dengan mendakwahkan La ilaha illa Allah, Nabi Muhłammad tidak hanya menolak berhala-hala yang dipasang di Ka'bah, tetapi juga menolak untuk mengakui otoritas kelompok kepentingan yang berkuasa dan struktur sosial yang ada pada masanya.

Orang-orang kafir Mekkah lebih merasa terusik oleh implikasi-implikasi revolusioner teolog Muhłammad ketimbang dakwahnya yang menantang penyembahan berhala. Semua tokoh penentangnya berasal dari kelas pedagang kaya yang merasa terancam otoritas dan dominasi mereka. Ancaman itu dirasakan

\footnotetext{
${ }^{5}$ Al-Qur'an (34:37)

${ }^{6}$ Muhammad Ahmad Khalfallah, Muhammad wa Quwwa al-Muwadadah (Kairo, I973) hal. I I3-

4.
}

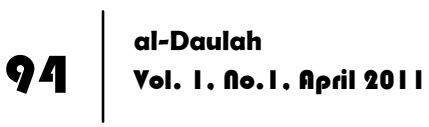


begitu serius sehingga mereka memutuskan untuk menyiksa para pengikut Muhłammad kapan dan di manapun. Karena alasan tersebutlah, Nabi memerintahkan para pengikutnya untuk hijrah ke Medinah, tempat di mana dia memperoleh dukungan dan jaminan tertentu. Bahkan sekelompok pengikutnya ada yang sudah lebih dulu hijrah ke Ethiopia.

Nabi Muhłammad, dengan inspirasi wahyu ilahiyah menurut formulasi teologis, mengajukan sebuah alternatif tatanan sosial yang adil dan tidak eksploitatif serta menentang penumpukkan kekayaan di tangan segelintir orang (oligarki). Memang rumusan Al-Qur'an lebih bersifat teologis, tidak sosiologis, seperti pada umumnya sistem berpikir yang dirumuskan pada masa kenabian, tetapi semua orang akan melihat betapa rumusan-rumusan itu mempunyai implikasi-implikasi sosial yang sangat besar. Distribusi kekayaan yang berlebih kepada kelompok masyarakat yang lemah diistilahkan dengan infaq fi sabilillah. Al-Qur'an mengutuk orang-orang yang menimbun emas dan perak, tidak menafkahkannya di jalan Allah serta meminta Nabi untuk memperingatkan mereka, bahwa hukuman yang berat menunggu mereka. Dengan struktur ekonomi yang berlaku dalam masyarakat ketika itu, maka satu-satunya jalan untuk memberikan perlindungan bagi orang-orang yang lemah adalah memberi tanggung jawab kepada orang-orang kaya untuk membagikan kelebihan kekayaan di jalan Allah.

Al-Qur'an, di samping mendakwahkan cita-cita Islam, tidak pernah mengabaikan konteks situasinya dan, sebenarnya hal inilah yang menjadi rahasia keberhasilannya. Misalnya ia tidak mengambil pendekatan kelas dengan jelas, karena pendekatan itu hampir-hampir tidak akan berfungsi dalam situasi sejarah berikutnya. Al-Qur'an membenci perbudakan, tapi tidak segera menghapusnya begitu saja. Perbudakan bukan merupakan bagian integral dari sistem ekonomi di Mekkah. Meskipun begitu, perbudakan tetap menjadi masalah yang sangat penting. Terlepas dari dukungan biaya yang bisa diperoleh Nabi dari tokoh-tokoh

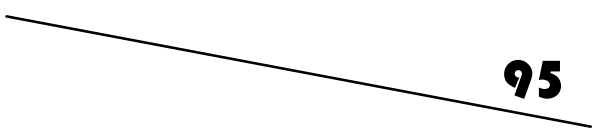


penting di Mekkah dan Medinah, penghapusan perbudakan bisa menimbulkan masalah baru yang tak terpecahkan pada masa permulaan Islam. ${ }^{7}$ Nabi menempuh cara-cara gradual untuk menghapuskan perbudakan. Nabi juga memberikan hak-hak budak yang sebelumnya terabaikan. Namun, sayangnya konteks sejarah belum matang untuk pembebasan budak secara total, dan karenanya, alih-alih melemah, lembaga perbudakan malah semakin menguat setelah Nabi wafat. Setelah imperium Byzantium dan Persia berhasil ditaklukkan, Islam berubah menjadi feodal (feudalised) dan menjadi kekuatan yang eksploitatif yang terlembaga selama tiga dekade serta telah kehilangan elan pembebasannya. Para ahli hukum Islam berhadapan dengan situasi kesejarahan yang konkrit, melakukan kodifikasi hukum syari'ah di bawah pengaruh atmosfir tersebut, dan dengan demikian mereka juga kehilangan elan pembebasan Islam-awal. "Kerusakan berat" pada elan pembebasan dan progresivitas Islam ini telah ditimbulkan oleh para ahli teologi dan ahli hukum Islam dengan cara mengaburkan apa yang diperintah oleh batasan-batasan situasional. Generasi berikutnya mengikuti mereka secara tidak kritis dan dengan demikian terciptalah suatu tatanan syari'ah yang kaku dan tidak dapat diubah.

Sementara itu, ulama masa kini--dengan semangat tidak kritis yang sama--menganggap hukum-hukum yang dirumuskan oleh ulama terdahulu sama dengan kebijaksanaan Ilahi dan mempunyai validitas abadi. Mereka juga mengabaikan fakta bahwa kebijaksanaan Ilahiyah bersifat transendental, melampaui batas-batas ruang dan waktu. Salah satu fungsi Tuhan yang essensial adalah rububiyyah yang didefinisikan oleh Imam Raghib Asfahani sebagai membimbing ciptaan-Nya melalui tahap-tahap evolusi yang berbeda ke arah kesempurnaan. ${ }^{8}$ Jika kebijaksanaan

${ }^{7}$ Untuk uraian lengkap mengenai masalah perbudakan, lihat Asghar Ali Engineer, The Origin and Development of Islam, op. cit.,

${ }^{8}$ Lihat Mufradat Imam Raghib; lihat Maulvi Muhammad Taqi Amini, Islam ka Zar'l Nizam (Delhi, 198I) hal. 13 
ilahiyah harus tetap berlaku, para ulama mestinya berupaya terus menerus untuk memecahkan ketegangan antara yang aktual dan yang mungkin, yang nyata dan yang ideal, yang sementara dan yang abadi.

Pada periode permulaan Islam di Mekkah, kaum muslimin merupakan minoritas kecil yang berhadapan dengan pedagangpedagang kaya Mekkah yang mapan dan kuat. Mereka hampirhampir tidak bisa mengangkat senjata menghadapi penantangpenantangnya yang kuat itu. Dalam menghadapi penindasan seperti itu, satu-satunya jalan yang mereka tempuh adalah pindah ke suatu negeri yang lebih aman dan hal ini dilakukan oleh kaum Muslimin setelah mendapat perintah Nabi. Mula-mula serombongan kaum Muslimin hijrah ke Ethiopia dan rombongan berikutnya hijrah ke Medinah. Kemudian Nabi juga ikut bergabung. Beberapa orang dari suku Aus dan Khazraj bergabung dengan Nabi dan di sana nabi menyusun kekuatan. Di Medinah juga terdapat beberapa suku Yahudi yang cukup berpengaruh. Nabi membuat suatu kesepakatan dengan berbagai suku, termasuk kaum Yahudi, dalam upayanya membentuk sebuah masyarakat yang kohesif.

Kesepakatan bersama yang dilakukan Nabi bersama-sukusuku yang ada di Madinah lebih dikenal dengan sebutan “ Piagam Madinah “.

\section{Politik Islam dalam Piagam Madinah}

Islam adalah agama moral kolektif yang mengandung berbagai etika dalam kehidupan sosial manusia, akan tetapi sumber utama Islam Al-Quran dan Hadits- tidak banyak berbicara secara khusus tentang ilmu pemerintahan dan politik, artinya sumber Islam jarang berbicara tentang cara membentuk negara, menjalankan pemerintahan, dan bagaimana mengelola organisasi. Tidak ada dalam sumber Islam yang menyatakan tentang sebuah teori politik yang sesuai dengan ajarannya. Namun demikian dari kenyataan sejarah pula kita dapat melihat hubungan yang erat

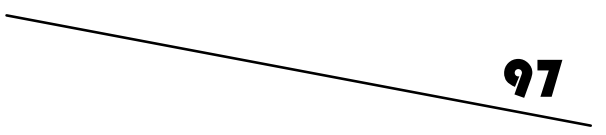


antara Islam dan Negara melalui Piagam Madinah yang menjadi bukti keberhasilan Nabi Muh\}ammad dalam membangun Kota Madinah menjadi sebuah Negara Kota (city state), barangkali bisa dikatakan bahwa Piagam Madinah merupakan titik tolak berkembangnya sejarah perpolitikan Islam, sehingga kita dapat mengambil beberapa prinsip yang mungkin dapat direkomendasikan mengenai peran Islam dalam kehidupan berbangsa dan bernegara. Namun begitu kaum cendekiawan sampai saat ini masih berdebat mengenai perlu atau tidaknya Islam menjadi konstitusi dalam sebuah negara. Sejarah perpolitikan Islam terus berkembang terutama setelah Nabi Muh\}ammad SAW wafat yang kemudian banyak bermunculan persoalan keumatan, diantaranya adalah persoalan pemerintahan, kepemimpinan Islam, siapa yang berhak mengganti Nabi Muh\}ammad sebagai khalifah, dan cara memilih khalifah tersebut.

Setidaknya ada tiga pandangan di kalangan umat Islam tentang hubungan antara Islam dan ketatanegaraan. Pertama, menganggap bahwa Islam adalah agama sempurna yang mengatur segala aspek kehidupan manusia, termasuk sistem ketatanegaraan (politik).

Kedua, menganggap bahwa Islam adalah agama dalam versi Barat yang tidak berhubungan dengan ketatanegaraan. Ketiga, berpendirian bahwa Islam bukanlah agama yang lengkap yang mengantur semua aspek kehidupan, termasuk ketatanegaraan dan menolak anggapan bahwa Islam adalah agama dalam pengertian Barat yang hanya mengatur hubungan manusia dengan penciptanya. Aliran ini berpendirian bahwa sekalipun dalam Islam tidak terdapat sistem ketatanegaraan, tetapi terdapat seperangkat tata nilai etika bagi kehidupan bernegara.

Di kalangan para cendikiawan dan pengamat politik Muslim Indonesia, banyak yang mengatakan bahwa dalam ajaran Islam terdapat kesesuaian (compatibility) antara Islam dan masyarakat Madani (civil sociaty).Pada intinya, disepakati bahwa Islam mendorong terciptanya masyarakat madani. Apa yang dilakukan 
Nabi Muh\}ammad dalam membangaun kota medinah merupakan contoh aktualnya. Nabi Muhłammad bukan saja membuat kesepakatan piagam madinah, tetapi juga mengganti nama Yasrib menjadi madinah, yang tentu saja merupakan salah satu cognate istilah " madinah " itu sendiri. ${ }^{9}$

Dalam Piagam Madinah yang merupakan perjanjian tertulis antara Nabi dengan komunitas Yatsrib (Madinah) dapat digambarkan bagaimana peran politik nabi sebagai seorang bangsawan yang mampu menyatukan berbagai komunitas yang beragam. Diawali oleh satu proses yang panjang ketika Nabi bertemu dengan 6 orang komunitas Madinah dari suku Khazraj di Aqabah pada musim haji tahun $620 \mathrm{M}$. Setelah melekukan bai'at. ke enam orang itu kembali ke Madinah dan menceritakan pertemuannya dengan Nabi, sekaligus mengajak masyarakat Madinah memeluk Islam. Sejak saat itu nama Nabi, Muh\}ammad menjadi bahan pembicaraan hangat di kalangan masyarakat Madinah. ${ }^{10}$

Banyak klaim di antara para ahli mengenai naskah konstitusi tertulis pertama dalam sejarah umat manusia. Bahkan kode sipil Hammurabi juga dinisbatkan oleh beberapa sarjana sebagaii konstitusi tertulis pertama dalam sejarah. Akan tetapi, apabila dibaca dengan perspektif modern dewasa ini tentang makna undang-undang dasar sebagai konstitusi tertulis, maka naskah pertama yang berisi hasil-hasil kesepakatan bersama antar warga masyarakat yang ditunjukkan oleh adanya tandatangan bersama antar tokoh-tokoh yang mewakili pelbagai kelompok yang beraneka ragam dalam masyarakat, tidak lain adalah Piagam Madinah $^{11}$.

\footnotetext{
${ }^{9}$ Azumardi Azra, Menuju Masyarakat Madani, ( Bandung :Remaja Rosdakarya, 1999) hal.3

${ }^{10}$ Ibnu Ishaq menyebut piagam karena ia adalah suatu naskah, tertulis yang dibuat oleh Nabi sebagai suatu perjanjian antar golongan Muhajirin, Anshor, Yahudi yang mengakui kebebasan beragama, menjamin harta benda mereka, menetapkan kewajiban-kewajiban mereka dan menjamin hah-hak mereka. Lihat: Ibnu Katsir, al-Bidayat wa alNihayat, jilid III. (Beirut: Dar alFikr, 1978), h. 224.

"Montgomery Watt bahkan menyebutnya sebagai "The Constitution of Medinah", lihat Muhammad: Prophet and Statesman,( Oxford University Press, 1964 ) hal. 93.
}

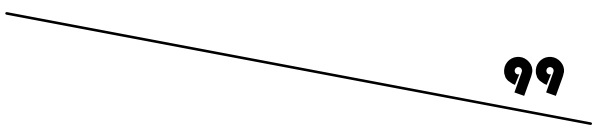


Piagam Madinah tersebut ditandatangani bersama oleh 13 kepala suku dan kelompok-kelompok dalam masyarakat bersama nabi Muhłammad pada tahun 622M ${ }^{12}$. Ketiga belas kepala suku tersebut adalah (i) kaum Muhajirin atau orang Islam yang berasal dari Mekkah, (ii) kaum Anshar atau orang Islam yang memang hidup di kota Madinah, (iii) kaum Yahudi dari banu 'Awf, (iv) kaum Yahudi dari banu Sa'idah, (v) kaum Yahudi dari banu Hars, (vi) kaum Yahudi dari banu Jusyam, (vii) kaum Yahudi dari banu al-Najjar, (viii) kaum Yahudi dari banu Amr ibn 'Awf, (ix) kaum Yahudi dari banu al-Nabit, (x) kau Yahudi dari banu al-'aws, (xi) kaum Yahudi dari banu Sa'labah, (xii) suku Jafnah dari banu Sa'labah, dan (xiii) suku banu Syuthaybah. Tercatat dalam sejarah, suku yang terakhir ini pernah berkhianat dan kemudian kepala suku dihukum oleh rasulullah dengan hukuman mati.

Prinsip ketaatan kepada kesepakatan para pemimpin dalam bentuk piagam perjanjian bersama itu, dalam Islam, sangat diberi tekanan. Dalam QS. Dinyatakan, "Athi'ullaha, wa athi'urrasula, wa ulil-amri minkum". Allah memerintahkan kepada orang-orang yang beriman untuk menaati Allah, menaati Rasulullah, dan para pemimpin di antara kamu. Salah satu bentuknya kumpulan kepemimpinan itu adalah perkumpulan para tokoh yang mewakili kelompok dan golongan kaumnya masing-masing untuk menandatanganni kesepakatan bersama untuk hidup bersama sebagai satu kesatuan masyarakat di Madinah.

Pertemuan tersebut kemudian berlanjut pada musim haji berikutnya $(621 \mathrm{M})$ antara Nabi dengan 12 orang Madinah, sekaligus melakukan bai'at. Peristiwa ini kemudian dikenal dengan bai'at "Aqabah pertama". Lalu disusul dengan bai'at kedua $622 \mathrm{M}$ pada musim haji berikutnya. Pada bai'at kedua ini mereka mengakui Nabi sebagai pemimpin mereka dan menjaga keselamatan beliau serta pengikutnya. Sebaliknya Nabi juga menyatakan perjanjian dengan mereka. Bai'at ini mengandung arti

12 Jimly Asshiddiqie, Pengantar IImu Hukum Tata Negara, Rajagrafindo Persada, Jakarta, edisi 2009, hal.85-86. 
bahwa telah terjadi "perjanjian persekutuan" antara Nabi dengan masyarakat Yatsrib. Oleh para pemikir Islam bai'at pertama dan kedua ini dianggap sebagai fundamen batu pertama negara Islam. Dengan bai'at ini pula Nabi menganjurkan untuk hijrah ke Madinah. Setelah beberapa bulan kemudian disusul oleh Nabi.

Beberapa waktu kemudian, khususnya setelah hijrahnya Nabi ke Madinah, Nabi memaklumatkan suatu piagam dengan komunitas Madinah dan kemudian dikenal dengan "Piagam Madinah". Tentang waktu yang pasti, tanggal berapa perjanjian tersebut dibuat, tidak ada data yang pasti apakah tahun I H, atau sebelum dan sesudah perang Badr. Dalam hal ini banyak terdapat, pandangan. Namun menurut Watt. para sarjana umumnya sepakat bahwa Piagam Madinah dibuat pada permulaan periode Madinah tahun I H. ${ }^{13}$ Wellhausen menetapkannya sebelum perang Badr. ${ }^{14}$

Konsep perjanjian yang oleh para ahli politik Islam, dianggap sebagai konstitusi Madinah atau undang-undang bagi negara Islam yang pertama yang dirikan Nabi di Madinah tersebut menurut al-Thabari ${ }^{15}$ dan ibn al-Atsir. ${ }^{16}$ Ditulis dalam dua peristiwa. Pertama dibuat oleh Nabi antara Muhajirin dan Anshor. Kedua yang dibuat. oleh Nabi dengan melibatkan kaum Yahudi. ${ }^{17}$ Kedua naskah tersebut kemudin oleh para ahli sejarah dipersatukan menjadi satu naskah.

Tentang keotentikannya, para ahli umumnya sepakat bahwa naskah naskah Piagam Madinah tersebut dilihat dari aspek muatan, bahasa dan ditinjau ilmu hadis adalah cukup otentik. Dari segi muatannya, seperti yang dikatakan Watt, ${ }^{18}$ Wellhausen $^{19}$, dan

13 W. Montgomery Watt, Muhammad Prophet and Statesman, (London: Oxford University Press, 1969), h. 93.

${ }^{14}$ W. Montgomery Watt, Muhammad at Medina, (London: Oxford University Press, 1956), h. 225-226.

${ }^{15}$ Al-Thabari, Tarikh al-Umam wa al-Mulk, jilid III, (Beirut: Dar al-Fikr, 1987), h. 84.

${ }^{16}$ Ibn al-Atsir, al-Kamil fi al-Tarikh, Jilid II, (Beirut: Dar al-Fikr, 1965), h. 187.

${ }^{17}$ Akram Umri, Tarikh al-Islam, (t.tt: College of al-Imam al-'Azham, 1972-1973), h. 12-I3.

${ }^{18}$ Watt, Muhammad Prophet and Statesman, op. cit., h. 94.

${ }^{19}$ Watt, Muhammad at-Madena, op. cit., h. 22-25.

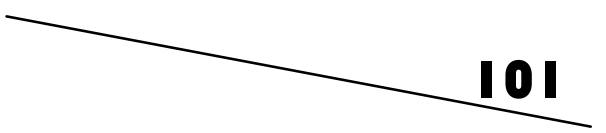


Winsinck ${ }^{20}$ naskah tersebut menggambarkan peta sosiologis dari situasi politik pada zamannya.

Dari segi bahasa. Shahih Ahmad al-'Ali berpendapat bahwa keaslian piagam tersebut tercermin pada uslub redaksinya. Teks yang dengan kalimat-kalimat pendek, pengulangan-pengulangan yang ditulis dalam satu pola yang menggabarkan semangat zamannya akan tetapi sekalipun teksteksnya pendek-pendek dan singkat, muatan yang terkandung cukup padat.

Dari segi ilmu hadis, naskah tersebut juga cukup otentik; karena lahirnya piagam tersebut adalah hasil perbuatan Nabi, oleh sebab itu ia termasuh hadis. Apalagi dibuktikan dengan banyaknya perawi hadis yang meriwayatkan adanya perjanjian yang dibuat oleh Nabi dan gambaran garis besarnya dari berbagai jalur atau sumber dengan sanad yang bervariasi. Salah satunya misalnya yang diriwayatkan oleh Bukhari. ${ }^{21}$ Peristiwa para imam hadis tidak menyebut teks piagam yang ada hanya sanad dan teks yang menyatakan adanya perjanjian tersebut dan garis besar isinya. Teks yang lengkap justru terdapat pada kitab-kitab sejarah.22

Sekalipun demikian, berdasarkan analisa-analisa yang dilakukan Para ahli hadis terhadap hadis tentang perjanjian Nabi dengan komunitas Madinah tersebut adalah tergolong hadis Shahih. Dari segi perawinya tergolong kategori hadis masyhur (hadis yang diriwayatkan 3 orang atau lebih yang tidak mencapai derajat mutawatir. ${ }^{23}$

${ }^{20}$ A.J. Wensinck, Muhammad and Jews at Madena, (t.tt: Freibug in Breisgan, 1975), h. 56.

${ }^{21}$ Al-Bukhari, Shahih Bukhari, Jilid III, Juz. 8, (Beirut: Dar al-Syaab, t.th), dan Jilid II, Juz. 4, h. 84 dan h. 122.

${ }^{22}$ Seperti pada karya Ibn Ishaq, al-Bidayat wa al-Nihayat, Jilid II, h. 23 I-233; Ibn Hisyam, al-Sirat al-Nabawiyyah, jilid III h. 244-246. Ibn Sallam dalam kitab al-anwal, h. 260. Teks piagam ini telah diterjemahkan ke dalam berbagai bahasa asing antara lain; Urdu, Turki, Prancis, Jerman, Itali, Belanda dan Indonesia.

${ }^{23}$ Mahmud al-Thahhan, Tafsir Musthalah Hadis, (Beirut: Dar al-Qur'an al-Karim, 198I), h. 10. 


\section{Relasi Islam dan Negara}

Hubungan Islam sebagai agama (din) dan negara (dawlah) hakikatnya merupakan dua satuan sejarah yang berbeda. Agama, menurut Kuntowijoyo, adalah peringatan (basyira wa nazira), sedangkan negara adalah kekuatan pemaksa. Agama mempunyai khatib, jiwa dakwah dan ulama, sedangkan negara mempunyai birokrasi pengadilan dan tentara. Agama dapat mempengaruhi jalannya sejarah melalui kesadaran bersama (collective conscience). Sedangkan negara mempengaruhi sejarah dengan keputusan kekuasaan dan perang. Agama adalah kekuatan dari dalam dan negara adalah kekuatan dari luar ${ }^{24}$.

Diskursus Agama dan negara selalu menjadi perdebatan, mengingat masalah ini menjadi salah satu subyek penting dalam kajian siyasah (politik), Walaupun menurut Azyumardi Azra25 telah diperdebatkan para pemikir Islam sejak hampir seabad lalu hingga dewasa ini, tetapi tetap belum terpecahkan dengan tuntas. Diskusi tentang hal ini bahkan belakangan semakin hangat tatkala antusiasme "kebangkitan Islam" melanda hampir seluruh dunia Islam. Pengalaman masyarakat Muslim di berbagai penjuru dunia, khususnya sejak usai Perang Dunia II mengesankan terdapatnya hubungan yang canggung antara Islam (din) dan negara (dawlah) atau bahkan politik pada umumnya. Berbagai "eksperimen" dilakukan untuk menyelaraskan antara din dengan konsep dan kultur masyarakat Muslim, dan eksperimen-eksperimen itu dalam banyak hal sangat beragam. ${ }^{26}$

Ada tiga paradigma dalam kajian tentang hubungan agama dan negara. Masing-masing ketiga paradigma ini berangkat dari konseptualisasi yang berbeda satu dengan lainnya. ${ }^{27}$

\footnotetext{
${ }^{24}$ Kuntowijoyo, Identitas Politik Umat Islam, (Bandung: Mizan dan Ummat, cetakan I, 1997), hlm. |9|-2.

${ }^{25}$ Azyumardi Azra, Jaringan Ulama, hlm. I.

26 Ibid.

27 Din Syamsuddin, Etika Agama d alam Membangu n Masyarakat Madani, (Jakarta: Logos, 2002), hlm. 57.
}

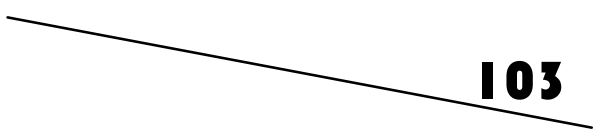


Perbedaan konseptual tersebut disebabkan pengistilahan yang berpasangan, seperti dunia-akhirat, umur al-dunya-umur aldin, din-dawlah, yang dikenal dalam sumber- sumber Islam:

Paradigma pertama memperkenalkan konsep bersatunya agama dan negara. Agama (Islam) dan negara dalam hal ini tidak dapat dipisahkan (integrated). Menurut paradigma ini, negara merupakan lembaga politik dan keagamaan sekaligus. Pemerintahan negara diselenggarakan atas dasar "kedaulatan ilahi" (divine sovereignity), karena memang kedaulatan itu berasal dan berada di "tangan" Tuhan. ${ }^{28}$

Kelompok Syi'ah yang banyak menganut Paradigma seperti ini. Paradigma pemikiran syi'ah memandang bahwa negara (imamiah) adalah lembaga keagamaan dan mempunyai fungsi keagamaan. Berhubung legitimasi keagamaan berasal dari Tuhan dan diturunkan lewat garis keturunan nabi Muhłammad, maka legitimasi politik harus berdasarkan legitimasi keagamaan dan hal ini hanya dimiliki oleh keturunan Nabi.

Dalam perspektif syi'ah, Negara lebih cenderung bersifat teokratis karena ia merupakan lembaga politik yang didasarkan atas legitimasi keagamaan dan mempunyai fungsi menyelenggarakan kedaulatan Tuhan. Negara teokrasi mengandung pengertian bahwa kekuasaan mutlak berada di tangan Tuhan dan konstitusi negara berdasarkan pada wahyu tuhan (syari'ah). Sifat teokratis negara dalam pandangan syi'ah dapat ditemukan dalam pemikiran-pemikiran ulama Syi'ah. Imam Khomeini umpamanya, menyatakan bahwa dalam negara Islam wewenang menetapkan hukum berada pada Tuhan. Tiada seorang pun berhak menetapkan hukum. Hukum yang boleh berlaku hanyalah hukum Tuhan. ${ }^{29}$

Selain kelompok Syiah, ada juga kelompok lain yang sering berpegangan pada Paradigma pemikiran ini yaitu mereka yang

\footnotetext{
${ }^{28}$ Ibid., hlm. 58

29 Karya Imam Khomeini yang banyak menjelaskan tentang "Negara Islam" adalah buku alHukumah al-Islamiyah, (Teheran: Muktabah al-Islamiyah al-Kubra, t.t.).
} 
sering dikategorikan sebagai "Fundamentalisme Islam", menurut mereka Islam adalah agama yang sempurna dan lengkap bagi pengaturan segala aspek kehidupan manusia, termasuk kehidupan bernegara. Al-Mawdudi (w. 1979) mengatakan bahwa syari'ah tidak mengenal pemisahan antara agama dan politik atau antara agama dan negara. Syari'ah adalah skema kehidupan yang sempurna dan meliputi seluruh tatanan kemasyarakatan, tidak ada yang lebih dan tidak ada yang kurang. ${ }^{30}$

Pendapat Mawdudi tentang negara dalam pandangan Islam adalah Pertama, Islam adalah suatu agama yang paripurna, lengkap dengan petunjuk untuk mengatur semua segi kehidupan manusia termasuk kehidupan politik dengan arti di dalam Islam terdapat pula sistem politik. Kedua, kekuasaan tertinggi yang dalam istilah politik disebut kedaulatan berada di tangan Allah dan umat manusia hanyalah pelaksana dari kedaulatan Allah tersebut sebagai khalifah-khalifah Allah di bumi. Ketiga, sistem politik Islam adalah batas-batadan ikatan-ikatan geografi bahasa dan kebangsaan. ${ }^{31}$

Paradigma kedua memandang antara agama dan negara tidak berhubungan sama sekali (terpisah). Menurut aliran ini Nabi Muh\}ammad hanyalah seorang rasul biasa seperti halnya rasulrasul sebelumnya, dengan tugas tunggal mengajak manusia kembali kepada kehidupan yang mulia dengan menjunjung tinggi budi pekerti luhur, dan nabi tidak pernah dimaksudkan untuk mendirikan dan menggali satu negara. Dalam konteks Islam, paradigma ini dikenal dengan paradigma sekularistik yang menolak pendasaran negara kepada Islam, atau paling tidak menolak determinasi Islam akan bentuk tertentu dari negara.

Salah seorang pemrakarsa paradigma ini adalah Ali Abdul alRaziq (1888-1966 M). Ia pengikut pemikiran Mohammad Abduh,

${ }^{30}$ Abul al-A'la Maududi, "Political Theory of Islam" dalam Kurshid Ahmad (ed.), Islamic Law and Constitution, (Lahore, 1967), hlm. 243.

${ }^{31}$ Munawir Sjadzali, Islam dan Tata Negara: Ajaran, Sejarah dan Pemikiran, (Jakarta: UI Press, edisi kelima, 1993), hlm. 66.

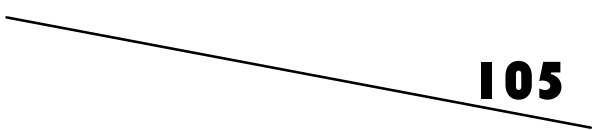


meskipun mungkin tidak sempat belajar darinya karena ketika Abduh wafat pada tahun 1905 M Ali baru berusia kirakira tujuh belas tahun. Ali Abdul al-Raziq merupakan tokoh yang paling kontroversial, dan karenanya paling terkenal terutama karena buku yang ditulisnya pada tahun $1925 \mathrm{M}$ dengan judul al-Islam wa Usul al-Hukm (Islam dan Prinsip-prinsip Pemerintahan). ${ }^{32}$

Paradigma ketiga hubungan agama dan negara memandang bahwa agama dan negara berhubungan secara timbal balik dan saling memerlukan. Dalam hal ini agama memerlukan negara, karena dengan negara agama dapat berkembang. Sebaliknya negara memerlukan agama karena dengan agama negara dapat berkembang dalam bimbingan etika dan moral. ${ }^{33}$

Salah satu tokoh yang mengembangkan paradigma pemikiran ini adalah al- Mawardi (w. 1058 M). Nama lengkapnya adalah Abu Hasan Ali b. Habib al- Mawardi al-Bashri, yang hidup antara tahun $346 \mathrm{H} / 975 \mathrm{M}$ dan $450 \mathrm{H} / 1059 \mathrm{M}$. Ia seorang pemikir Islam terkenal, tokoh terkemuka mazhab Syafi'i, dan pejabat tinggi yang besar pengaruhnya dalam pemerintahan Abbasiyah. Setelah berpindah-pindah dari satu kota ke kota lain sebagai hakim, akhirnya ia kembali dan menetap di Baghdad, dan mendapat kedudukan yang terhormat pada pemerintahan Khalifah Qadir. ${ }^{34}$

Pada masa sekarang ini terdapat beberapa perbedaan pendapat ulama tentang relasi agama dan politik, ada yang mengatakan terpola pada dua mainstream antara Islam Formal (tekstualis) dan Islam Substantif (liberal) . Pertama, Islam Formal adalah sebuah faham yang mengusung konsep \&ldquo;al-Islam dien wa dawlah\&rdquo; dalam arti Islam adalah Agama dan Negara. Faham ini beranggapan bahwa Islam haruslah menjadi

\footnotetext{
32 Argumen utama Ali abd al-Raziq adalah bahwa kekhalifahan tidak mempunyai dasar dalam alQur'an dan al-hadis. Kedua sumber utama Islam ini tidak menyebut istilah khilafah dalam pergantian kekhalifahan yang pernah ada dalam sejarah. Lebih dari itu, tidak ada petunjuk yang jelas dalam al-Qur'an dan al-hadis yang menentukan suatu bentuk sistem politik yang harus didirikan oleh umat Islam. Lihat Ali 'Abd al-Raziq, Al-Islam wa Usul al-Hukm, cetakan I, (Kairo: Dar al Misr, I342/ 1925), hlm. 403.

${ }^{33}$ Dien Syamsuddin, Etika Agama, hlm. 60

${ }^{34}$ Munawir Sjadzali, Islam dan Tata Negara, hlm. 58
} 
dasar negara, bahwa syariah harus diterima sebagai konstitusi negara, kedaulatan politik ada di tangan Tuhan. Dalam pandangan mereka Islam harus mewarnai kehidupan, dan tidak boleh menjadi sekedar agama privat. Islam harus asertif menjadi dasar negara, dan syariatnya mesti diberlakukan dalam tiap sendi kehidupan berbangsa dan bernegara. Dalam faham ini pula dikatakan bahwa konsep negara bangsa (nation state) bertentangan dengan konsep ummah (komunitas Islam) yang tidak mengenal batas-batas politik atau kedaerahan.

\section{Daftar Pustaka}

'Abd al-Raziq, Ali, Al-Islam wa Usul al-Hukm, cetakan I, Kairo: Dar al Misr, 1342/ 1925.

Ahmad Khalfallah, Muhammad, Muhammad wa Quwwa alMuwadadah, Kairo, 1973.

Akram Umri, Tarikh al-Islam, t.tt: College of al-Imam al-'Azham, 1972-1973.

al-A'la Maududi, Abul, Political Theory of Islam; dalam Kurshid Ahmad (ed.), Islamic Law and Constitution, Lahore, 1967.

Al-Bukhari, Shahih Bukhari, Jilid III, Juz. 8, Beirut: Dar al-Syaab, t.th, dan Jilid II, Juz. 4.

Ali Engineer, Asghar, The Origin and Development of Islam, Orient and Longman, 1980.

Al-Thabari, Tarikh al-Umam wa al-Mulk, Jilid III, Beirut: Dar al-Fikr, 1987.

al-Thahhan, Mahmud, Tafsir Musthalah Hadis, Beirut: Dar al-Qur'an al-Karim, 1981.

Asshiddiqie, Jimly, Pengantar Ilmu Hukum Tata Negara, Rajagrafindo Persada, Jakarta, edisi 2009.

Azra, Azumardi, Menuju Masyarakat Madani, Bandung: Remaja Rosdakarya,1999.

Gibb, HAR, Mohammadanism, Oxford, 1969.

Ibn al-Atsir, al-Kamil fi al-Tarikh, Jilid II, Beirut: Dar al-Fikr, 1965.

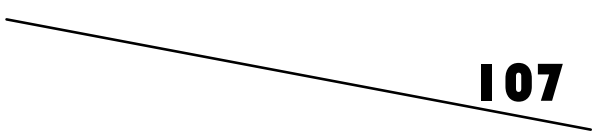


Ibn Hisyam, al-Sirat al-Nabawiyyah, jilid III.

Ibn Ishaq, al-Bidayat wa al-Nihayat, Jilid II.

Katsir, Ibnu, al-Bidayat wa alNihayat, Jilid III, Beirut: Dar al-Fikr, 1978.

Kuntowijoyo, Identitas Politik Umat Islam, Bandung: Mizan dan Ummat, cetakan I, 1997.

Petrovsky, A.P, Islam da Iran, Persian, diterjemahkan oleh Karim Kashawarz, Teheran, 1950.

Sjadzali, Munawir, Islam dan Tata Negara: Ajaran, Sejarah dan Pemikiran, Jakarta: UI Press, edisi kelima, 1993.

Syamsuddin, Din, Etika Agama dalam Membangun Masyarakat Madani, Jakarta: Logos, 2002.

Taqi Amini, Maulvi Muhammad, Islam ka Zar'I Nizam, Delhi, 1981.

Watt, M. Montgomery, Muhammad at Medina, London: Oxford University Press, 1956.

Watt, M. Montgomery, Muhammad, Prophet and Statesman, Oxford University Press, 1964.

Wensinck, A.J., Muhammad and Jews at Madena, t.tt: Freibug in Breisgan, 1975. 